\title{
FIVE NEW COMBINATIONS AND ONE NEW NAME IN RUBIACEAE FROM SOUTH-EAST ASIA
}

\author{
AARON P. DAVIS \& MARKUS RUHSAM \\ The Herbarium, Royal Botanic Gardens, Kew, \\ Richmond, Surrey, TW9 3AE, United Kingdom
}

\begin{abstract}
SUMMARY
Five new combinations and one new name are proposed for six Rubiaceae species from South-East Asia. Four new combinations are proposed in Cyclophyllum and one in Psychotria; a new name is proposed for one Psychotria species.
\end{abstract}

Key words: Amaracarpus, Canthium, Cyclophyllum, Plectronia, Psychotria, Rubiaceae, South-East Asia.

\section{INTRODUCTION}

Taxonomic studies in the Rubiaceae by Bridson (1987) and Davis \& Bridson (2004) enumerate species for which new combinations are needed. Herein we take the opportunity to propose five new combinations and one new name (nomen novum), as based on the aforementioned studies, viz. Cyclophyllum caudatum (Valeton) A.P. Davis \& Ruhsam, C. longiflorum (Valeton) A.P. Davis \& Ruhsam, C. novoguineensis (Miq.) A.P. Davis \& Ruhsam, C. valetonianum (S. Moore) A.P. Davis \& Ruhsam, Psychotria montisgiluwensis A.P. Davis \& Ruhsam, and P. montisstellaris (P. Royen) A.P. Davis \& Ruhsam.

\section{NEW COMBINATIONS IN CYCLOPHYLLUM}

Cyclophyllum Hook.f. (Vanguerieae Dumort.) is a genus restricted to SE Asia, Australasia and the Pacific (see Bridson 1987: 614, map 1). Bridson (1987: 616) lists eight species of Canthium Lam. that should be considered for transfer to Cyclophyllum, viz. Canthium barbatum (Forst.) Seem., C. brevipes Merr. \& L.M. Perry, C. caudatum (Valeton) S. Moore, C. coprosmoides F. Muell., C. costatum C.T. White, C. longiflorum (Valeton) Merr. \& L.M. Perry, C. sessilifolium A. Gray, and C. valetonianum S. Moore. Five of the above species were later transferred to Cyclophyllum, leaving three species (C. caudatum, C. longiflorum, and C. valetonianum), all from New Guinea, potentially requiring new combinations in Cyclophyllum. In addition, we have identified another member of the Vanguerieae from New Guinea, Plectronia novoguineensis (Miq.) Valeton, which should be placed in Cyclophyllum. Canthium caudatum and C. longiflorum have also been placed in Plectronia L., but the use of this generic name has to be restricted to the family Oliniaceae, as Plectronia is a generic synonym of 
Olinia Thunb. (Ross, 1975: 491; Verdcourt, 1987: 127). Plectronia was formerly used in the Rubiaceae as the generic name for a large number of species, mostly belonging to the tribe Vanguerieae and in particular Canthium.

There are only two genera of Vanguerieae in New Guinea: Cyclophyllum and Psydrax Gaertn., although the informal group Pyrostria 'group B' was recognised by Bridson (1987). Pyrostria ' group B' is a group of taxa that may either constitute a new genus or perhaps a disjunct part of Pyrostria (Bridson, pers. comm.). In New Guinea Pyrostria 'group B' is confined to the Kepala Burung (Vogelkop Peninsula), in the extreme NW part of the island. A key separating Cyclophyllum and Pyrostria 'group B' is given by Bridson (1987: 614).

The morphological differences separating Cyclophyllum and Psydrax are considerable, and they can be easily separated on the basis of easily definable morphological differences (e.g. see Reynolds \& Henderson, 1999: 354). According to molecular data provided by Lantz \& Bremer (2004: 263) Cyclophyllum is convincingly associated with the 'dioecious Pyrostria group', and Psydrax is a well-supported monophyletic unit.

Canthium does not occur in New Guinea, although several taxa from New Guinea have been placed in the genus. On morphological grounds their placement is erroneous (Bridson, 1987), a fact that is supported by molecular data (Lantz \& Bremer, 2004).

We propose that three Rubiaceae species currently placed in Canthium and one in Plectronia should be transferred to Cyclophyllum: Cyclophyllum caudatum, C. longiflorum, $C$. novoguineensis, and $C$. valetonianum. The two type specimens bearing flowers (for C. longiflorum and C. valetonianum) have the salient characteristics of Cyclophyllum after Bridson (1987: 616): paired bracts absent; inflorescence fasciculate or occasionally with rudimentary inflorescence branches; corolla always hypocrateriform; style widening at apex; flowers hermaphrodite; ovary 2-locular. The two type specimens bearing fruit (C.caudatum and $C$.novoguineensis) possess the first two characters listed above and they have the characteristic elongated pedicel of Cyclophyllum. Specimens matching C. caudatum and C.novoguineensis held at the Kew herbarium (K) possess the floral characters of Cyclophyllum, as listed above.

\section{Cyclophyllum caudatum (Valeton) A.P. Davis \& Ruhsam, comb. nov.}

Basionym: Plectronia caudata Valeton (1911) 478. - Canthium caudatum (Valeton) S. Moore (1923) 24. - Type: Branderhorst 335 (holo ?BO; iso K, L), [Papua Barat], Nova Guinea neerlandica meridionalis, fluv. Noordrivier, pr. Bivak Sebong.

\section{Cyclophyllum longiflorum (Valeton) A.P. Davis \& Ruhsam, comb. nov.}

Basionym: Plectronia longiflora Valeton (1927) 56. - Canthium longiflorum (Valeton) Merr. \& L.M. Perry (1945) 232. - Type: Schlechter 18959 (holo B†; iso K, L), [Papua New Guinea], 'Kaiser-Wilhelmsland, In den Wäldern bei Toliba', 300 m, 14 July 1908.

Cyclophyllum novoguineensis (Miq.) A.P. Davis \& Ruhsam, comb. nov.

Basionym: Coffea ?novoguineensis Miq. (1869) 259. - Plectronia novoguineensis (Miq.) Valeton (1911) 478. - Type: Zippelius s.n. (holo ?U; iso L), [Papua Barat], Nova Guinea. 


\section{Cyclophyllum valetonianum (S. Moore) A.P. Davis \& Ruhsam, comb. nov.}

Basionym: Canthium valetonianum S. Moore (1923) 25. - Type: Forbes 61 (holo BM; iso L), Papua New Guinea, Sogere [Sogeri], $2500 \mathrm{ft}$ [762 m].

\section{A NEW NAME AND A NEW COMBINATION IN PSYCHOTRIA}

In a recent revision of Amaracarpus Davis \& Bridson (2004) informally placed Amaracarpus giluwensis $\mathrm{P}$. Royen and A. montisstellaris P. Royen (Van Royen, 1983) in Psychotria. With direct reference to the type species, $P$. asiatica L. (see Davis et al., 2001), these two species possess the salient characters of Psychotria. Specifically, A. giluwensis and A. montisstellaris have terminal inflorescences, bifid stipules, 5-merous flowers, yellow or white fruit (Van Royen, 1983: 2686, 2688, 2702; fruit colour in A. montisstellaris unknown); the pyrenes have marginal preformed germination slits, a seed coat with an ethanol soluble pigment, and ruminate endosperm (Davis, unpubl. data). These characters are not found in Amaracarpus (Davis \& Bridson, 2004: 25, 26), or the closely associate Dolianthus, which was formerly placed within Amaracarpus (see Davis \& Bridson, 2001: 421).

One new combination and one new name are proposed.

\section{Psychotria montisgiluwensis A.P. Davis \& Ruhsam, nom. nov.}

Amaracarpus giluwensis P. Royen (1983) 2686. - Type: Schodde 1869 (holo K; iso L), Papua New Guinea, western summit grasslands of Mt Giluwe, Southern Highlands District, c. 10,000 ft. [3050 m], 16 Aug. 1961.

Note - The new name $P$. montisgiluwensis is proposed because the name $P$. giluwensis is already being used in Psychotria (P. giluwensis Sohmer).

Psychotria montisstellaris (P. Royen) A.P. Davis \& Ruhsam, comb. nov.

Basionym: Amaracarpus montisstellaris P. Royen (1983) 2701. - Type: Veldkamp 6319 (holo L), Papua New Guinea, Star Mts, W Sepik, Camp 2, Tel Basin, 3000 m, 5 March 1975.

\section{ACKNOWLEDGEMENTS}

We would like to thank Diane Bridson for her suggestions and advice regarding Cyclophyllum and the Vanguerieae. Part of the work undertaken for this contribution was supported by the Global Biodiversity Information Facility (GBIF), within the Electronic Catalogue of Names of Known Organisms (ECAT) programme.

\section{REFERENCES}

Bridson, D.M. 1987. Studies in African Rubiaceae-Vanguerieae: a new circumscription of Pyrostria and a new subgenus, Canthium subgen. Bullockia. Kew Bull. 42: 611-639.

Davis, A.P. \& D.M. Bridson. 2001. A taxonomic revision of the genus Dolianthus (Rubiaceae). Blumea 46: 421-446.

Davis, A.P. \& D.M. Bridson. 2004. A taxonomic revision of the genus Amaracarpus (Rubiaceae, Psychotrieae). Blumea 49: 25-68. 
Davis, A.P., D.M. Bridson, C. Jarvis \& R. Govaerts. 2001. The typification and characterization of the genus Psychotria L. (Rubiaceae). Bot. J. Linn. Soc. 135: 35-42.

Lantz, H. \& B. Bremer. 2004. Phylogeny inferred from morphology and DNA data: characterizing well-supported groups in Vanguerieae (Rubiaceae). Bot. J. Linn. Soc. 146: 257-283.

Merrill, E.D. \& L.M. Perry. 1945. Plantae Papuanae Archboldianae. J. Arnold Arbor. 26: 229-266.

Miquel, F.A.W. 1869. Ecologe Rubiacearum archipelagi Indici. Ann. Mus. Lugduno-Batavi 4: $179-262$.

Moore, S. 1923. Gamopetalae in Dr. H.O. Forbes's New Guinea plants. J. Bot. 61 (suppl.): 23-39.

Reynolds, S.T. \& R. J.F. Henderson. 1999. Vanguerieae A. Rich. ex Dum. (Rubiaceae) in Australia: 1. Everistia S.T. Reynolds et R.J.F. Hend. Austrobaileya 5: 353-361.

Ross, J.H. 1975. The typification of Lycium inerme. Bothalia 11: 491-493.

Valeton, T. 1911. Rubiaceae. Nova Guinea 8, 1: 437-519.

Valeton, T. 1927. Die Rubiaceae von Papuasien. Bot. Jahrb. Syst. 61: 32-163.

Van Royen, P. 1983. The alpine flora of New Guinea. Vol. 4. Cramer, Vaduz.

Verdcourt, B. 1987. Notes on African Rubiaceae-Vanguerieae. Kew Bull. 42: 123-199. 